OPEN ACCESS

Edited by:

Su Shiung Lam,

University of Malaysia

Terengganu, Malaysia

Reviewed by:

Mukesh Kumar Awasthi,

Northwest A\&F University, China

Muhammad Aqeel Ashraf,

China University of Geosciences

Wuhan, China

Dangquan Zhang,

Henan Agricultural University, China

*Correspondence:

Liwei An

imaualw@126.com

Specialty section:

This article was submitted to

Bioenergy and Biofuels,

a section of the journal

Frontiers in Energy Research

Received: 11 December 2019

Accepted: 07 February 2020

Published: 25 February 2020

Citation:

An L (2020) The Method for Static Composting Treatment of the

Landscaping Waste.

Front. Energy Res. 8:24.

doi: 10.3389/fenrg.2020.00024

\section{The Method for Static Composting Treatment of the Landscaping Waste}

\author{
Liwei $A n^{1,2 *}$ \\ ${ }^{1}$ College of Agriculture, Inner Mongolia University for Nationalities, Tongliao, China, ${ }^{2}$ Institute of Ecological Civilization and \\ Green Development, Inner Mongolia University for Nationalities, Tongliao, China
}

In order to speed up the process of landscape garbage composting and reduce environmental pollution, the static composting method of landscape garbage was studied in depth. The spring landscape garbage in Beijing Xiangshan Park was used as the main raw material, and an appropriate amount of dried chicken manure was added for high-temperature composting experiments. Furfural residue was added to landscape waste compost, and the dynamic changes of compost quality, total nitrogen, carbon-nitrogen ratio, and plant inhibitors were studied. Through orthogonal experiments, chicken manure was used as a $\mathrm{C} / \mathrm{N}$ regulator, and bacteria and wood vinegar were used as additives. The total volume of each treatment, changes in $\mathrm{pH}$ and EC values, and seed germination index were analyzed and compared. The results show that this method reduces the bulk density of $39 \mathrm{mg} / \mathrm{kg}$, increases the total porosity by $11.6 \%$, and increases the water holding porosity by $7.74 \%$, which can significantly increase the $\mathrm{N}, \mathrm{P}$, and $\mathrm{K}$ content of landscape waste compost products and reduce the product. The bulk density of the fertilizer has increased the total porosity and water holding porosity of the fertilizer, and the quality of the fertilizer has been significantly improved.

Keywords: landscaping, waste, static, composting, treatment effect

\section{INTRODUCTION}

In recent years, with the rapid development of landscape industry in China, the city's green level and overall green volume are also constantly improving, followed by the rapid increase in the number of the landscape waste, which has become one of the main sources of urban solid waste (Antonio, 2016). How to deal with and utilize the huge amount of the landscape waste has become one of the problems to be solved in the research of urban ecological environment in China (Zhang et al., 2016). The landscape waste refers to the green trimmings, fallen leaves, dead branches, and grass scraps produced in urban greening maintenance, as well as the by-products produced in the operation of other industries (i.e., wood waste). If the treatment measures are improper, it will not only affect the beauty of urban human settlements, but also pollute the air, soil and groundwater, and cause permanent harm to the environment (Wu et al., 2016).

The traditional way of treating the landscape waste in China is landfill or incineration. Although the number of the landscape waste can be reduced, the two non environmental treatment methods cause serious air pollution and resource waste. On the one hand, the landfilling of the landscape waste will lead to a large number of land resources being occupied (Yang et al., 2016). At present, the amount of the landscape waste in China is increasing gradually. If it cannot be dealt with and utilized timely and effectively, the problem of its occupation of agricultural land will become more 
and more serious (Shahid et al., 2016). At the same time, the burning of the landscape waste will produce a large number of greenhouse gases and toxic gases such as dioxin and hydrogen sulfide, which will cause serious air pollution (Yang, 2016). On the other hand, excessive removal of the landscape waste will also cause the interruption of soil nutrient cycle, the decrease of organic matter content in the soil and the damage of soil acid-base environment. Finally, it leads to many problems such as soil surface hardening, salinization or sand dust (Svetlana et al., 2016). In fact, from the perspective of resource science, the landscape waste is not only a waste but also a resource, and it is a growing organic resource in the world. The landscape waste contains a certain amount of beneficial nutrients, a large number of lignin, cellulose, hemicellulose, and some organic substances. In the future, it will become an inevitable trend for social development to reuse it as a raw material that can participate in production (Qiao, 2016). Chen et al. (2018) found that the composting of landscape waste can not only reduce the landfill area and the propagation of pathogens, but also return it to the soil, which can increase the soil nutrient content. Improve the physical properties of soil and reduce the occurrence of urban dust, soil invasion, and surface runoff. At the same time, it also greatly reduces the maintenance cost of urban green space and drives the rapid development of circular economy. More importantly, compost product is a kind of substance similar to humus, which can be used as soil improver, organic fertilizer, and peat alternative matrix with remarkable effect. Therefore, the composting treatment of the landscape waste is the best environmental protection technology, which is also conducive to the development of environment and economy (Gao and Li, 2016).

Therefore, the recycling of the landscape waste is of strategic significance for the coordinated development of society, economy, and environment (Swarnam et al., 2016). The growth trend of the amount of the landscape waste in foreign countries is basically consistent with that in China, which is increasing with the rapid development of urban greening. For example, according to the data, EC countries produce about 2.5 billion tons of waste every year. Among them, the number of the landscape water accounts for more than half (Jin and Gao, 2016). Therefore, many foreign scholars have done a lot of research on the processing and reuse of the landscape waste. Vergara and Tchobanoglous (2012) has established a model of the cost of urban solid waste collection in the United States, and reduced the cost of collection to promote the recycling of the landscape waste; According to the situation of urban organic waste collection, according to the collection time, line and artificial needs, Everett and Shahi designed the method of street collection of the landscape waste (Wei et al., 2017). For the research on the resource-based processing of the landscape water, compared with foreign countries, it is still in the exploratory stage, and has not formed a series of related theoretical and technical support (Lin et al., 2016).

Landscape waste recycling has become an important way to achieve sustainable development of organic waste. It can make full and reasonable use of the garden ecosystem, reduce the negative impact of landscaping activities on the nature
TABLE 1 | Basic physical and chemical properties of composting materials.

\begin{tabular}{lccc}
\hline Material & Green waste & Chicken manure & Furfural residue \\
\hline Water content/\% & $20.11 \pm 0.83$ & $15.32 \pm 0.36$ & $36.06 \pm 0.56$ \\
$\mathrm{pH}$ & $5.790 \pm 0.15$ & $7.020 \pm 0.31$ & $2.840 \pm 0.18$ \\
Total nitrogen/\% & $0.730 \pm 0.09$ & $4.390 \pm 0.17$ & $0.89 \pm 0.02$ \\
$\mathrm{C} / \mathrm{N}$ ratio & $43.10 \pm 0.66$ & $7.570 \pm 0.24$ & $32.30 \pm 0.65$ \\
Bulk density $/ \mathrm{kg} / \mathrm{m}^{3}$ & $171.0 \pm 0.99$ & $861.0 \pm 10.07$ & $351.0 \pm 3.60$ \\
\hline
\end{tabular}

TABLE 2 | Experiment design of garden waste composting

\begin{tabular}{|c|c|c|c|}
\hline Handle & 1 & 2 & 3 \\
\hline Material & $\begin{array}{l}\text { Landscaping } \\
\text { waste }\end{array}$ & $\begin{array}{l}\text { Landscaping waste } \\
+ \text { chicken manure }\end{array}$ & $\begin{array}{l}\text { Landscaping waste }+ \\
\text { chicken manure }+ \\
\text { furfural residue }\end{array}$ \\
\hline $\mathrm{C} / \mathrm{N}$ ratio & $43.1 \pm 0.59$ & $25.1 \pm 0.35$ & $28.1 \pm 0.29$ \\
\hline
\end{tabular}

and the urban environment, and provide a new model for the development of circular economy in the garden industry. Therefore, a static combined treatment method for landscape waste is proposed, which provides theoretical and technical support for the static combined treatment of landscape pollutants.

\section{MATERIALS AND METHODS}

\section{Test Time and Place}

The field experiment was conducted in Beijing Xiangshan Park in May 2019, and the indoor experiment was conducted in the laboratory of soil science of Beijing Forestry University in August 2019 (Hanc et al., 2016).

\section{Test Materials}

\section{Effect of Furfural Residue on the Composting of the Landscaping Waste}

The landscape waste used in this experiment is the spring garden waste of Beijing Xiangshan Park, mainly the pruned branches and leaves of poplar and willow (Touceda-González et al., 2016). Furfural residue is provided by a furfural factory in Siping City, Jilin Province. Rinse with water before use to remove particles and water soluble substances attached to the surface of furfural residue, and dilute its own acidity. Then, air dry and standby under natural conditions (Bolocan et al., 2016). Chicken manure is obtained from dry chicken manure produced by a company in Shijiazhuang. The basic physical and chemical properties of each compost raw material are shown in Table 1.

There are three composting treatments, namely pure garden waste compost, garden waste compost with chicken manure, garden waste compost with furfural residue and chicken manure. The $\mathrm{C} / \mathrm{N}$ ratio of each treatment in the early stage is shown in Table 2.

Before composting, adjust the moisture content to 55$60 \%$, and pile into a pile with the height of about $1.5 \mathrm{~m}$. The ventilation is carried out by means of manual turning over, from the beginning of composting to the end of high 
TABLE 3 | Basic physicochemical properties of main composting materials.

\begin{tabular}{lcc}
\hline Raw material & Landscaping waste & Chicken manure \\
\hline Total nitrogen (\%) & 0.81 & 1.11 \\
Total organic carbon (\%) & 46.10 & 9.51 \\
C/N & 57.51 & 8.61 \\
Water content (\%) & 10.10 & 2.21 \\
\hline
\end{tabular}

TABLE 4 | Orthogonal experimental design $L_{9}\left(3^{4}\right)$.

\begin{tabular}{|c|c|c|c|c|}
\hline \multirow[t]{2}{*}{ Treatment } & \multicolumn{4}{|c|}{ Factor } \\
\hline & $\begin{array}{l}\text { Microbe } \\
\text { fungus }\end{array}$ & $\begin{array}{l}\text { Wood } \\
\text { vinegar }\end{array}$ & $\begin{array}{l}\text { Microbe fungus } x \\
\text { Wood vinegar }\end{array}$ & $\mathrm{C} / \mathrm{N}$ \\
\hline $\mathrm{C} / \mathrm{N} 21+\mathrm{W} / 951$ & $1(0)$ & $\begin{array}{l}1 \text { (951 times } \\
\text { dilution) }\end{array}$ & 1.1 & $1(21)$ \\
\hline C/N31 + W/501 & $1(0)$ & $\begin{array}{l}2 \text { (501 times } \\
\text { dilution) }\end{array}$ & 2.1 & $2(31)$ \\
\hline $\mathrm{C} / \mathrm{N} 41+\mathrm{W} / 51$ & $1(0)$ & $\begin{array}{l}3 \text { (51 times } \\
\text { dilution) }\end{array}$ & 3.1 & $3(41)$ \\
\hline $\begin{array}{l}\mathrm{C} / \mathrm{N} 41+0.3 \% \mathrm{M}+ \\
\mathrm{W} / 951\end{array}$ & $2(0.3 \%)$ & $\begin{array}{l}1 \text { (951 times } \\
\text { dilution) }\end{array}$ & 2.1 & $3(41)$ \\
\hline $\begin{array}{l}\mathrm{C} / \mathrm{N} 21+0.3 \% \mathrm{M}+ \\
\mathrm{W} / 501\end{array}$ & $2(0.3 \%)$ & $\begin{array}{l}2 \text { (501 times } \\
\text { dilution) }\end{array}$ & 3.1 & $1(21)$ \\
\hline $\begin{array}{l}\mathrm{C} / \mathrm{N} 31+0.3 \% \mathrm{M}+ \\
\mathrm{W} / 51\end{array}$ & $2(0.3 \%)$ & $\begin{array}{l}3 \text { (51 times } \\
\text { dilution) }\end{array}$ & 1.1 & $2(31)$ \\
\hline $\begin{array}{l}\mathrm{C} / \mathrm{N} 31+0.5 \% \mathrm{M}+ \\
\mathrm{W} / 951\end{array}$ & $3(0.5 \%)$ & $\begin{array}{l}1 \text { (951 times } \\
\text { dilution) }\end{array}$ & 3.1 & $2(31)$ \\
\hline $\begin{array}{l}\mathrm{C} / \mathrm{N} 41+0.5 \% \mathrm{M}+ \\
\mathrm{W} / 501\end{array}$ & $3(0.5 \%)$ & $\begin{array}{l}2 \text { (501 times } \\
\text { dilution) }\end{array}$ & 1.1 & $3(41)$ \\
\hline $\begin{array}{l}\mathrm{C} / \mathrm{N} 21+0.5 \% \mathrm{M}+ \\
\mathrm{W} / 51\end{array}$ & $3(0.5 \%)$ & $\begin{array}{l}3 \text { (51 times } \\
\text { dilution) }\end{array}$ & 2.1 & $1(21)$ \\
\hline
\end{tabular}

temperature, turning over once every 2 days; after the high temperature period, turning over once every 5 days until the compost is mature. During composting, samples were taken at $0,3.1,5.1,10.1,15.1,20.1,25.1,30.1,35.1$, and $40.1 \mathrm{~d}$ respectively, and relevant indexes were determined. It includes $\mathrm{pH}$ value, total nitrogen, alkali hydrolyzed nitrogen, available phosphorus, available potassium, bulk density, total porosity and water holding porosity (Zhu et al., 2016).

\section{The Effect of $\mathrm{C} / \mathrm{N}$, Adding Bacteria and Wood Sorrel on the Landscape Waste Composting}

The dead branches and dead leaves of plants pruned in autumn in Beijing Xiangshan Park were used as the main raw materials and chicken manure as the conditioner. The basic physical and chemical properties of the main composting materials are shown in Table 3.

The used fungicide is Sufubao organic material maturity fungicide, which is a kind of high-efficiency compound microbial fungicide, mainly composed of protein, fat, cellulose, chitin, etc. It has strong decomposition ability and fast decomposition speed, and is suitable for fast composting of a variety of different substrates (Ling et al., 2018). The wood vinegar used is the light yellow to reddish brown condensate produced by wood pyrolysis
TABLE 5 | Quality characteristics of compost products from landscaping wastes.

\begin{tabular}{lccc}
\hline Handle & $\mathbf{1}$ & $\mathbf{2}$ & $\mathbf{3}$ \\
\hline Hydrolyzable nitrogen/(mg/kg) & 58.18 & 66.84 & 80.52 \\
Available phosphorus/(mg/kg) & 6.04 & 8.78 & 10.99 \\
Available potassium/(mg/kg) & 128.22 & 151.30 & 201.64 \\
Bulk density/(mg/kg) & 139 & 122 & 83 \\
Total porosity/\% & 48.2 & 55.68 & 67.28 \\
Water holding porosity/\% & 24.19 & 27.74 & 35.48 \\
\hline
\end{tabular}

Different capitals and lowercase letters in the same column indicate significant and extremely significant differences in LSR test at the level of 0.05 and 0.01 respectively.

in the process of burning charcoal. It has the special smoky smell and is acidic.

The orthogonal design $L_{9}\left(3^{4}\right)$ of the interaction of $\mathrm{C} / \mathrm{N}$, fungus and wood vinegar (dilution ratio 3 ) is adopted, and the details are shown in Table 4.

According to the test design requirements, adjust the $\mathrm{C} / \mathrm{N}$ according to the weight ratio of the landscape waste and chicken manure, add the bacterial agent and mix well. Then add 951, 501, and 51 times of wood sorrel with equal volume dilution, spray and stir at the same time, so that the moisture content of the pile is about $65 \%$. This can not only meet the water content requirements, but also help to mix the wood vinegar evenly and save labor. Finally, the piles with length of $2 \mathrm{~m}$, width of $1.5 \mathrm{~m}$ and height of $1 \mathrm{~m}$ were made, respectively.

\section{Data Processing Method}

SPSS software was used for variance analysis and multiple comparisons of test data (LSD method); Microsoft Office Excel 2003 was used for data processing and chart drawing (Li et al., 2018).

\section{RESULTS}

\section{Effect of Furfural Residue on the Composting of the Landscape Waste Effect of Furfural Residue on the Quality of the Landscape Waste Compost}

The quality character of compost product is an important index to restrict whether compost can be used in agriculture or not, and it is also an important decisive factor to influence whether the municipal solid waste can realize its "resource." It can be seen from Table 5 that adding chicken manure and furfural residue can significantly improve the quality of compost products. The content of basic $\mathrm{n}$, available $\mathrm{P}$ and available $\mathrm{K}$ in the compost of treatment 3 with furfural residue was significantly higher than that of treatment 2 with pure chicken manure. Compared with treatment 1, treatment 2 increased $14.9 \%$ of basic n, $45.4 \%$ of available $\mathrm{P}$ and $18.0 \%$ of available K. Compared with treatment 2 , treatment 3 increased basic $\mathrm{n}$ by $20.5 \%$, available P by $25.2 \%$, and available $\mathrm{K}$ by $33.3 \%$. The effect of furfural residue on the quality of the landscape waste compost is shown in Table 5.

Compared with Treatment 1, Treatment 2 reduced the bulk density by $17 \mathrm{mg} / \mathrm{kg}$, increased the total porosity by $7.48 \%$, 


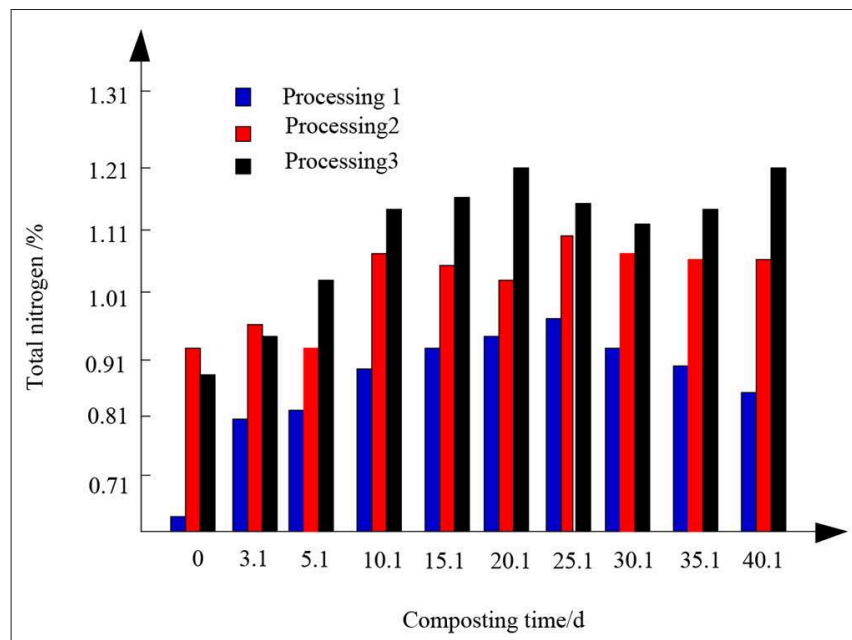

FIGURE 1 | Changes of total nitrogen content in different composting treatments.

and increased the water holding porosity by $3.55 \%$. Compared with Treatment 2, Treatment 3 reduced the bulk density by $39 \mathrm{mg} / \mathrm{kg}$, total porosity increased by $11.6 \%$, and water holding porosity increased by $7.74 \%$. The addition of chicken manure and furfural residues can effectively reduce the compost density and significantly increase the total porosity and water holding porosity of the compost product.

\section{Effect of Furfural Residue on Total Nitrogen Content in Landscape Waste Compost}

If the compost is not treated properly, a lot of nitrogen will be lost. When this kind of compost product is applied to the soil, not only the fertilizer effect is not high, but also it may capture the nitrogen in the soil and destroy the nutrient balance of the soil. The dynamic change of total nitrogen content in this composting process is shown in Figure 1.

From the test results, 3.1 days after composting, the total nitrogen content increased rapidly, then decreased and gradually flattened. At $20.1 \mathrm{~d}$, the total nitrogen content of treatment 3 increased to the highest. After composting, the total nitrogen content of each treatment was $0.87,1.05$, and 1.18 , respectively. Compared with treatment 1 , the total nitrogen content of pure chicken manure treatment 2 increased, while that of furfural residue treatment 3 was higher than that of treatment 2. Furfural residues can significantly increase the total nitrogen content during composting. The total nitrogen content of each treatment in the test showed an overall growth trend.

\section{Effect of Furfural Residue on C/N Ratio in Landscape Waste Composting}

Generally speaking, when the $\mathrm{C} / \mathrm{N}$ ratio of compost is below 21, it is considered that the compost is mature. The effect of furfural residue on the $\mathrm{C} / \mathrm{N}$ ratio of the landscape waste compost is shown in Figure 2.

It can be seen from Figure 2 that in the whole composting process, the $\mathrm{C} / \mathrm{N}$ ratio obtained by different treatment methods

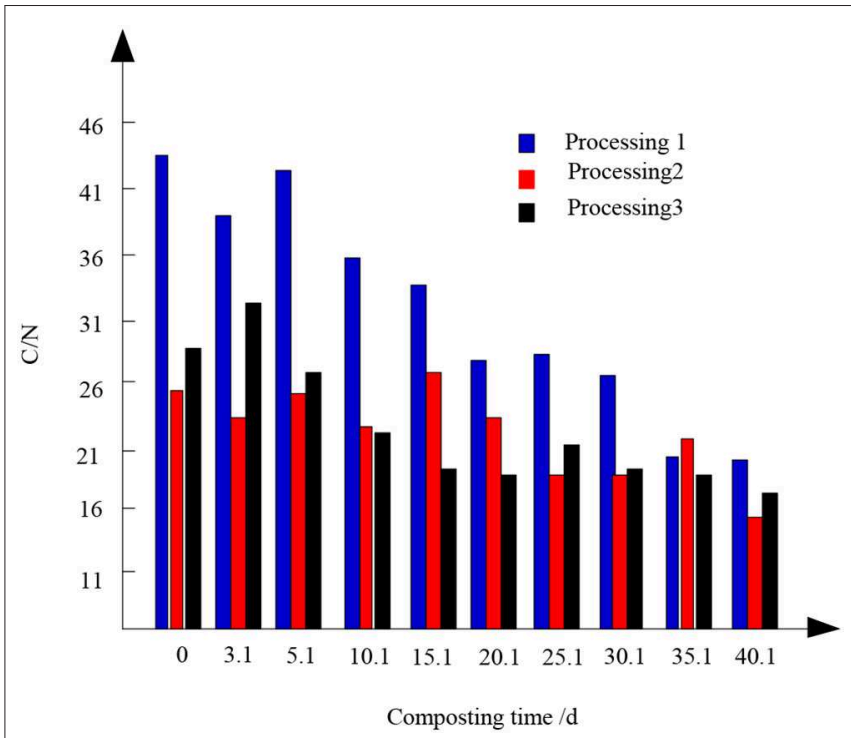

FIGURE 2 | The change of C/N ratio in different composting treatments.

shows the downward trend, and finally achieves relative stability. In the composting process, although the decline trend of treatment 1 is obvious, at the end of the composting cycle, its $\mathrm{C} / \mathrm{N}$ ratio is only 21 , which does not meet the requirements of composting maturity. The $\mathrm{C} / \mathrm{N}$ of treatment 2 and treatment 3 decreased from 25 and 28 at the beginning to 17 and 16 at the end of composting, which indicated that the addition of furfural residue had a positive effect on $\mathrm{C} / \mathrm{N}$ in composting. This is mainly because in the early stage of composting, with the increase of temperature, the microbial activity in the reactor is strong, the decomposition of organic matter in the reactor is intense, and the carbon content decreases faster than the nitrogen loss. Therefore, the overall $\mathrm{C} / \mathrm{N}$ ratio decreased, while the content of carbon in furfural residue was rich, and the content of organic matter easy to be decomposed by microorganisms was more, so the $\mathrm{C} / \mathrm{N}$ ratio of treatment 3 with furfural residue decreased significantly compared with other treatments.

\section{Effect of Furfural Residue on Degradation of Plant Inhibitor in the Landscape Waste Compost}

The degradation of organic matter in composting will produce many intermediate products. Immature compost is rich in organic acids, polyphenols, and other plant growth inhibitors, which are gradually transformed or disappeared with the composting process. Through the germination index (GI) of plant seeds, the degradation of plant inhibitors can be determined rapidly. Generally speaking, when GI $>0.50$, compost is considered to be basically non-toxic, and GI $>0.80$, compost is considered to be completely mature. In this experiment, water celery seed is selected as the indicator plant of germination test, and the test results are shown in Figure 3.

In the composting, GI increased with time. However, the GI value of compost decreased from 3.1 to $10.1 \mathrm{~d}$, which may be due to the inhibition of $\mathrm{NH}_{4}^{+}-\mathrm{N}$ and organic acid produced by 
microbial degradation of organic matter on water celery seeds. At $20.1 \mathrm{~d}$, the germination indexes of celery seeds treated with different methods were $0.59,0.73$, and 0.81 , respectively. The GI value of treatment 2 was higher than that of treatment 1 , and that of treatment 3 with furfural residue was higher than that of treatment 2. After composting, the germination indexes of the three treatments were 73,87 , and $90 \%$, respectively. Except treatment 1 , the other two treatments have reached the compost maturity standard.

\section{Effect of C/N Regulation and Addition of Bacteria and Wood Sorrel on the Composting of the Landscape Waste Changes of Bulk Volume, pH, and EC Value Before and After Composting With Different Treatments}

With the passage of time, the gap between the piles becomes smaller and smaller, and the volume of the piles gradually

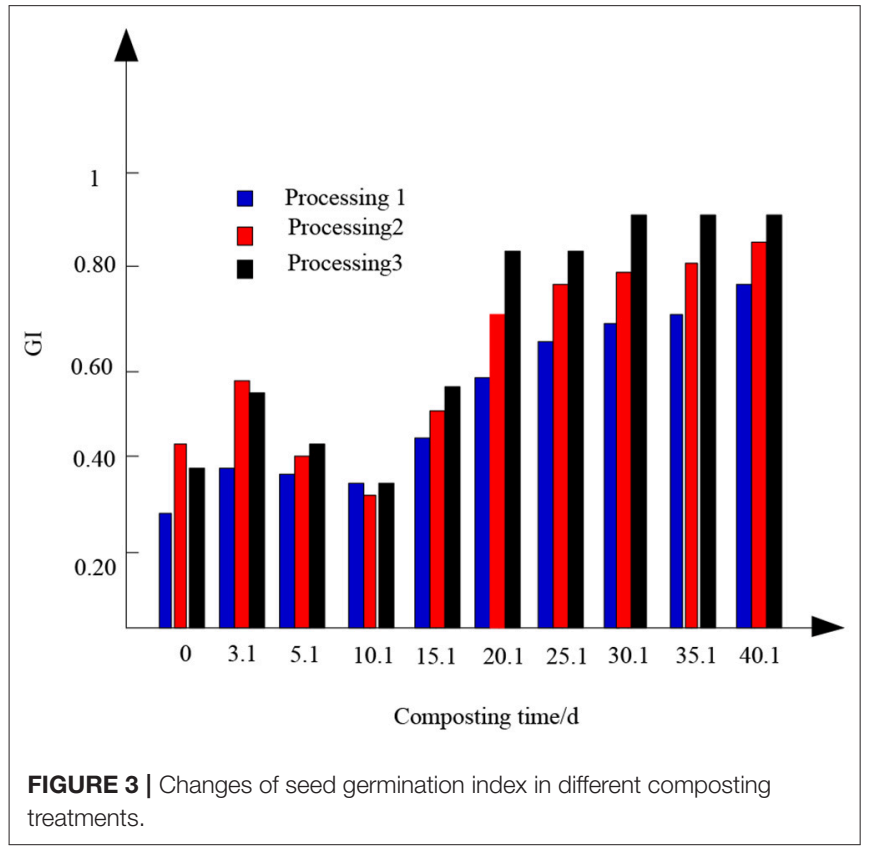

decreases. By the end of composting, the volume of compost obtained by $\mathrm{C} / \mathrm{N} 41+0.5 \% \mathrm{~m}+\mathrm{W} / 501$ treatment was the smaller than that of the initial treatment, and the volume change caused by $\mathrm{C} / \mathrm{N} 21+\mathrm{W} / 951$ treatment was the least. The $\mathrm{pH}$ value not only affects the decomposition of organic matter, the oxidation-reduction of minerals and the activity intensity of microorganisms, but also directly affects the biochemical reaction speed participated by enzymes. It is one of the important indexes to evaluate the maturity of compost.

The $\mathrm{pH}$ value of each treatment increased from the beginning to the end of composting. The increase of $\mathrm{pH}$ value is caused by the decomposition of organic matter and the production of $\mathrm{NH}_{3}$.

As shown in Table 6, the rising range of $\mathrm{pH}$ value of compost obtained by each treatment method is different. Before and after composting, the $\mathrm{pH}$ value of compost obtained by $\mathrm{C} / \mathrm{N} 41+0.3 \% \mathrm{~m}+\mathrm{W} / 951$ and $\mathrm{C} / \mathrm{N} 31+0.5 \% \mathrm{~m}+\mathrm{W} / 951$ treatments changed the most. This is because the $\mathrm{C} / \mathrm{N}$ of compost treated by these two methods is higher, enough carbon sources provide necessary nutrients for the growth and reproduction of microorganisms, and the degradation degree of organic matter is higher. However, the addition of exogenous bacteria makes the decomposition of organic matter more intense, and the volatile part of $\mathrm{NH}_{3}$ fills the compost, which makes the $\mathrm{pH}$ of the compost increase continuously.

It can be seen from Table 6 that the $\mathrm{pH}$ of compost can be reduced by adding wood vinegar under certain $\mathrm{C} / \mathrm{N}$ conditions. This phenomenon may be due to the acidity of wood sorrel. Adding wood sorrel provides a lot of $\mathrm{H}+$ for composting, which reacts with $\mathrm{NH}_{3}$ to form $\mathrm{NH}_{4}^{+}$dissolved in water, and reduces the $\mathrm{pH}$. It can be seen that the proper $\mathrm{C} / \mathrm{N}$ regulation and the addition of fungicides are conducive to the increase of compost $\mathrm{pH}$, while wood sorrel can reduce the $\mathrm{pH}$ of compost products. The $\mathrm{pH}$ value specified in the organic fertilizer standard is 5.58.0 , and the $\mathrm{pH}$ value of each treatment in this compost does not meet the organic fertilizer standard. It can be seen that the use of compost products also needs to add other additives according to the actual situation to reduce $\mathrm{pH}$.

The size of EC is related to the salt content of compost. The EC of compost used as soil conditioner should not be too large, otherwise it will affect the normal growth of crops. From the data analysis in Table 6, it is found that the EC Value of the

TABLE 6 | Variations of volume, $\mathrm{pH}$ value, and EC value of the composting at the start and the end of different treatments.

\begin{tabular}{|c|c|c|c|c|c|c|c|c|c|}
\hline \multirow[t]{2}{*}{ Treatment } & \multicolumn{3}{|c|}{ Volume } & \multicolumn{3}{|c|}{ PH } & \multicolumn{3}{|c|}{ EC } \\
\hline & Start & End & Decrease & Start & End & Increase & Start & End & Increase \\
\hline $\mathrm{C} / \mathrm{N} 21+\mathrm{W} / 951$ & 0.57 & 0.52 & 8.98 & 7.3 & 8.1 & 11.2 & 1,153 & 2,331 & 103 \\
\hline C/N31 + W/501 & 0.57 & 0.35 & 39.25 & 6.9 & 8.6 & 25.1 & 1,091 & 1,537 & 42 \\
\hline $\mathrm{C} / \mathrm{N} 41+\mathrm{W} / 51$ & 0.56 & 0.42 & 25.98 & 6.5 & 7.4 & 14.2 & 1,032 & 1,307 & 28 \\
\hline $\mathrm{C} / \mathrm{N} 41+0.3 \% \mathrm{M}+\mathrm{W} / 951$ & 0.57 & 0.32 & 44.88 & 6.6 & 8.7 & 32.4 & 1,041 & 1,215 & 18 \\
\hline $\mathrm{C} / \mathrm{N} 21+0.3 \% \mathrm{M}+\mathrm{W} / 501$ & 0.57 & 0.42 & 27.86 & 7.2 & 8.6 & 19.8 & 1,130 & 1,961 & 75 \\
\hline $\mathrm{C} / \mathrm{N} 31+0.3 \% \mathrm{M}+\mathrm{W} / 51$ & 0.55 & 0.39 & 30.27 & 6.8 & 8.4 & 23.8 & 1,073 & 1,452 & 36 \\
\hline $\mathrm{C} / \mathrm{N} 31+0.5 \% \mathrm{M}+\mathrm{W} / 951$ & 0.58 & 0.34 & 42.51 & 6.8 & 8.8 & 32.9 & 1,104 & 1,272 & 16 \\
\hline $\mathrm{C} / \mathrm{N} 41+0.5 \% \mathrm{M}+\mathrm{W} / 501$ & 0.58 & 0.3 & 50.01 & 6.5 & 8.3 & 28.2 & 1,037 & 1,117 & 9 \\
\hline $\mathrm{C} / \mathrm{N} 21+0.5 \% \mathrm{M}+\mathrm{W} / 51$ & 0.59 & 0.48 & 18.53 & 7.3 & 7.8 & 6.8 & 1,148 & 2,217 & 94 \\
\hline
\end{tabular}




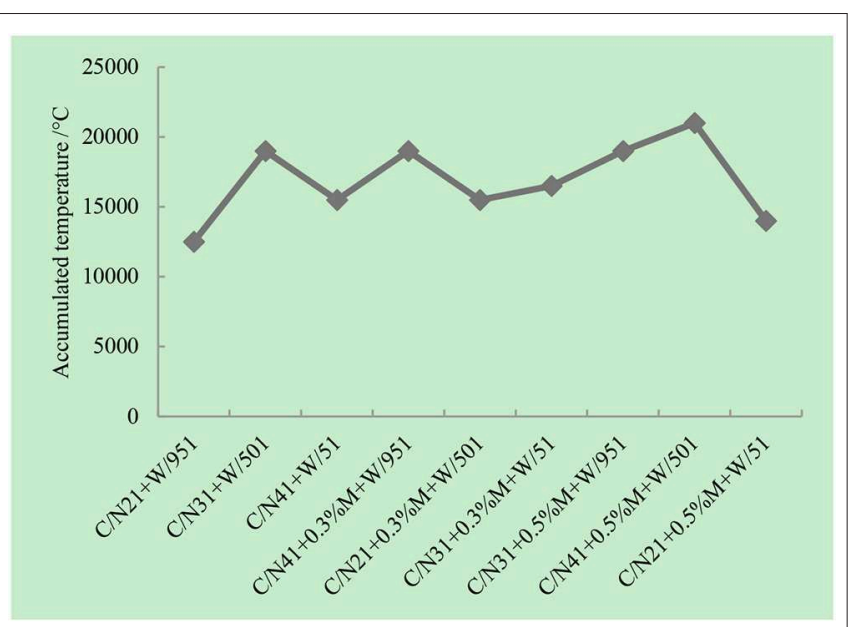

FIGURE 4 | Compost accumulated temperature of different treatments.

finished compost is higher than that of the raw material. The lower the $\mathrm{C} / \mathrm{N}$ was, the higher the $\mathrm{EC}$ value was, and the lower the EC value was. The increase of EC Value of compost products is caused by a large number of ammonium ions and mineral salts produced in the compost and the gradual decrease of the volume of the compost. However, the low EC Value of compost with proper amount of bacteria and wood vinegar is due to the accelerated decomposition of compost materials, the formation of more humus and the reduction of $\mathrm{EC}$ value. It can be seen that the regulation of $\mathrm{C} / \mathrm{N}$ and the addition of bacteria and wood sorrel can prevent the EC Value of compost products from being too high and improve the quality of compost products.

\section{Compost Accumulated Temperature Changes of Different Treatment Methods}

It has been shown that the accumulated temperature can be used as an important parameter to consider both temperature intensity and holding time in the composting process, which is related to the composting process and maturity of compost. The compost accumulated temperature of different treatment methods is shown in Figure 4.

It can be seen from Figure 4 that the compost treated by $\mathrm{C} / \mathrm{N} 41+0.5 \mathrm{~m}+\mathrm{W} / 501$ has the largest accumulated temperature, while the compost treated by C/N21 + W/951 has the smallest accumulated temperature. It can be seen that the higher the $\mathrm{C} / \mathrm{N}$ ratio is, the higher the composting temperature is, and the addition of proper amount of bacteria and wood sorrel can improve the composting temperature.

From the point of view of temperature change and accumulated temperature, $\mathrm{C} / \mathrm{N} 31+\mathrm{W} / 501, \mathrm{C} / \mathrm{N} 41+0.3 \% \mathrm{~m}$ $+\mathrm{W} / 951, \mathrm{C} / \mathrm{N} 31+0.5 \% \mathrm{~m}+\mathrm{W} / 951, \mathrm{C} / \mathrm{N} 41+0.5 \% \mathrm{~m}+$ $\mathrm{W} / 501$ had the best fermentation effect, and the high temperature retention time and accumulated temperature were longer in the whole fermentation stage. However, the compost treated with $\mathrm{C} / \mathrm{N} 41+\mathrm{W} / 51$ and $\mathrm{C} / \mathrm{N} 21+0.5 \% \mathrm{~m}+\mathrm{W} / 51$ had the lowest accumulated temperature and the shortest duration of high temperature, which may be related to the lack of effective carbon source at low $\mathrm{C} / \mathrm{N}$ and the lack of effective nitrogen source at high $\mathrm{C} / \mathrm{N}$ and the inhibition of microbial quantity by adding high concentration of wood vinegar. The addition of proper amount of bacteria and wood sorrel can advance and prolong the high temperature period of compost and shorten the fermentation period of compost. The reason may be that the addition of fungicides increased the total number of microorganisms in the pile layer, while the addition of appropriate amount of wood vinegar provided food for microorganisms. This makes the microorganisms in the compost layer propagate rapidly and maintain at a relatively stable high level, which makes the high temperature period of compost come ahead of time. At the same time, a certain amount of microorganisms can rapidly decompose the organic matter in the compost, so as to accelerate the compost maturity and greatly shorten the composting time.

\section{Germination Index (GI)}

Table 7 shows the analysis results of the variance of the orthogonal test.

Table 8 shows the significance test results of differences between different treatments and factor effects.

It can be seen from Table 7 that there is no significant difference in GI among the treatment repeats, and the interaction among $\mathrm{C} / \mathrm{N}$, fungicide, wood sorrel, fungicide and wood sorrel is extremely significant, which shows that the interaction among $\mathrm{C} / \mathrm{N}$, fungicide, wood sorrel, fungicide, and wood sorrel is an important factor affecting GI.

It can be seen from Table 8 that the range of $\mathrm{C} / \mathrm{N}$ is the largest, which shows that $\mathrm{C} / \mathrm{N}$ has the greatest influence on GI of compost, and wood vinegar has the smallest influence among the three factors. This is related to the degradation rate of organic matter in compost mainly depends on $\mathrm{C} / \mathrm{N}$, rather than the number or species of microorganisms. The comparison between composting treatments and multiple comparison of the effects of various factors (Table 8) shows that the treatment effect is the best when the $\mathrm{C} / \mathrm{N}$ is 31 , the effect is the best when the amount of bacteria is $0.4 \%$, and the effect of wood vinegar is the best when the dilution is 501 times. When the $\mathrm{C} / \mathrm{N}$ is 41 and the wood sorrel is diluted 51 times, the effect is poor, which may be related to the lack of effective nitrogen source to inhibit microbial activity under the condition of high $\mathrm{C} / \mathrm{N}$, and the high concentration wood sorrel also has a certain inhibition effect on microbial activity. $\mathrm{F}$ test showed that the interaction between $0.5 \%$ bacteria and 501 times diluted wood sorrel was the most significant, and the interaction between $0.5 \%$ bacteria and 501 times diluted wood sorrel was significantly different from other levels. The interaction value between the added amount of each fungus and the 51 times diluted wood sorrel solution was negative, which indicated that the 51 times diluted wood sorrel solution had a certain inhibition on the effect of fungus.

In this experiment, the GI value of the compost treated by $\mathrm{C} / \mathrm{N} 31+0.5 \% \mathrm{~m}+\mathrm{W} / 951$ method is larger than that of C/N41 $+0.5 \% \mathrm{~m}+\mathrm{W} / 501$ treatment, and the difference is significant, which shows that the interaction between $0.4 \%$ bacteria and the diluted 501 times wood vinegar is large. However, the effect of $\mathrm{C} / \mathrm{N}$ on $\mathrm{GI}$ was much greater than that of $0.5 \%$ fungicide and 501 times diluted wood sorrel. The GI of C/N21 + W/951, 
TABLE 7 | Analysis of variance of orthogonal test.

\begin{tabular}{|c|c|c|c|c|c|c|c|c|}
\hline $\begin{array}{l}\text { Source of } \\
\text { variation }\end{array}$ & $\begin{array}{l}\text { Processing } \\
\text { room }\end{array}$ & $\begin{array}{l}\text { Repeating } \\
\text { room }\end{array}$ & $\begin{array}{l}\text { Microbial } \\
\text { inoculum }\end{array}$ & $\begin{array}{l}\text { Wood } \\
\text { vinegar }\end{array}$ & $\mathrm{C} / \mathrm{N}$ & $\begin{array}{l}\text { C/inoculant } x \\
\text { Wood vinegar }\end{array}$ & Error & Total \\
\hline df & 8.1 & 2.1 & 2.1 & 2.1 & 2.1 & 4.1 & 16.1 & 26.1 \\
\hline SS & 8858.2 & 78.58 & 2551.21 & 2224.86 & 3629.72 & 452.46 & 297.13 & 9233.93 \\
\hline MS & 1107.3 & 39.28 & 1275.61 & 1112.43 & 1814.87 & 113.12 & 18.58 & \\
\hline$F$ & $59.64^{\star \star}$ & 2.13 & $69.68^{\star \star}$ & $59.91^{\star \star}$ & $97.74^{\star \star}$ & $6.08^{\star \star}$ & & \\
\hline$F_{0.05}$ & 2.58 & 3.24 & & & & 3.02 & & \\
\hline$F_{0.01}$ & 3.88 & 6.24 & & & & 4.78 & & \\
\hline Range & & & 23.64 & 21.63 & 28.25 & & & \\
\hline
\end{tabular}

${ }^{*}$ Conspicuousness.

TABLE 8 | Significance test of difference between different treatments and factor effect.

\begin{tabular}{|c|c|c|c|c|c|c|c|c|}
\hline \multirow[t]{2}{*}{ Treatment } & \multicolumn{2}{|c|}{$\begin{array}{l}\text { Multiple comparisons } \\
\text { between processes }\end{array}$} & \multicolumn{6}{|c|}{ Multiple comparison of various factors } \\
\hline & GI (\%) & Saliency & Level & GI (\%) & Saliency & Level & GI (\%) & Saliency \\
\hline C/N21 + W/951 & 68.78 & e D & \multicolumn{3}{|c|}{ Microbial inoculum } & \multicolumn{3}{|c|}{ Wood vinegar } \\
\hline C/N31 + W/501 & 98.58 & $\mathrm{c} \mathrm{BC}$ & 1.1 & 79.18 & C C & 1.1 & 94.86 & b A \\
\hline $\mathrm{C} / \mathrm{N} 41+\mathrm{W} / 51$ & 70.23 & $e D$ & 2.1 & 93.54 & b B & 2.1 & 101.17 & a A \\
\hline $\mathrm{C} / \mathrm{N} 31+0.3 \% \mathrm{M}+\mathrm{W} / 51$ & 96.07 & ed BC & & & & & & \\
\hline $\mathrm{C} / \mathrm{N} 31+0.5 \% \mathrm{M}+\mathrm{W} / 951$ & 125.92 & a A & 1.1 & 78.62 & C C & $\mathrm{M}_{2} \mathrm{~W}_{2}$ & 6.29 & b B \\
\hline $\mathrm{C} / \mathrm{N} 41+0.5 \% \mathrm{M}+\mathrm{W} / 501$ & 110.23 & $b \mathrm{AB}$ & 2.1 & 106.86 & a A & $\mathrm{M}_{2} \mathrm{~W}_{2}$ & -22.14 & $d D$ \\
\hline \multirow[t]{2}{*}{$\mathrm{C} / \mathrm{N} 21+0.5 \% \mathrm{M}+\mathrm{W} / 51$} & 72.35 & eD & 3.1 & 90.11 & b B & $\mathrm{M}_{3} \mathrm{~W}_{2}$ & 44.05 & a A \\
\hline & & & & & & $M_{3} W_{3}$ & -8.11 & a A \\
\hline
\end{tabular}

$\mathrm{C} / \mathrm{N} 41+\mathrm{W} / 51, \mathrm{C} / \mathrm{N} 20+0.5 \% \mathrm{~m}+\mathrm{W} / 51$ was the smallest and the difference between them was not significant, which did not meet the standard of no toxicity to plants. This shows that too high or too low $\mathrm{C} / \mathrm{N}$ is not conducive to the improvement of compost maturity, which may be related to the fact that low $\mathrm{C} / \mathrm{N}$ will make EC too high, too high salt will inhibit the normal germination of seeds, and high $\mathrm{C} / \mathrm{N}$ will make the compost nutrient content low. The difference of GI value between $\mathrm{C} / \mathrm{N} 21$ $+0.3 \% \mathrm{~m}+\mathrm{W} / 501$ and $\mathrm{C} / \mathrm{N} 21+\mathrm{W} / 951$ and $\mathrm{C} / \mathrm{N} 21+0.5 \%$ $\mathrm{m}+\mathrm{W} / 51$ treatment was extremely significant, which indicated that the addition of proper amount of bacteria and wood vinegar could effectively improve the maturity of compost. Therefore, the optimal combination of $\mathrm{C} / \mathrm{N}$, fungicide and wood sorrel was determined as $\mathrm{C} / \mathrm{N} 31+0.5 \% \mathrm{~m}+\mathrm{W} / 501$, that is, $\mathrm{C} / \mathrm{N} 31+0.5 \%$ fungicide + dilution 501 times wood sorrel.

\section{DISCUSSION}

(1) The importance of preprocessing: The degradation resistance of lignocellulose is an important factor limiting the effective transformation of landscape litter. Exploring an effective method for removing lignin from lignocellulose will help shorten the maturation time of landscape waste compost and improve the compost efficiency. Guangzhou Institute of Landscape Architecture has developed three chemical maturation agents: 1,1cyclohexanediacetic acid (CDA), 4,4'-bis (9-carbazolyl)-2, 2'-dimethylbiphenyl (CDB), and Cinnamyl 3,4-dihydroxyalpha- cyanocinnamate (CDC) chemistry, combined with the results of SEM, IR, and XRD, we can see that after pretreatment with chemical curing agent, the wall swelled and the wall thickness of lignocellulose increased by more than $25 \%$. Because the chemical bond between lignin and cellulose was partially destroyed, the crystal structure of the lignocellulose crystal region was destroyed, and the relative crystallinity was reduced by more than $2.6 \%$. It can be seen that chemical maturation agents have good application potential in landscape waste composting.

(2) By the end of composting, the volume of compost obtained by $\mathrm{C} / \mathrm{N} 41+0.5 \% \mathrm{~m}+\mathrm{W} / 501$ treatment was the smaller than that of the initial treatment, and the volume change caused by C/N21 + W/951 treatment was the least. When the $\mathrm{C} / \mathrm{N}$ content of compost is fixed, adding wood sorrel can reduce the $\mathrm{pH}$ of compost, which may be due to the acidity of wood sorrel. The addition of wood sorrel provides a large amount of $\mathrm{H}+$ for composting, which reacts with $\mathrm{NH} 3$ to form $\mathrm{NH}+4$ dissolved in water, reducing $\mathrm{pH}$. The $\mathrm{EC}$ values of the compost products were higher than those of the raw materials, and the lower the $\mathrm{C} / \mathrm{N}$ was, the higher the $\mathrm{EC}$ values were, and the lower the $\mathrm{EC}$ values of the compost products were.

(3) The accumulated temperature of compost treated with $\mathrm{C} / \mathrm{N} 41+0.5 \mathrm{~m}+\mathrm{W} / 501$ method was the largest, and that of compost treated with $\mathrm{C} / \mathrm{N} 21+\mathrm{W} / 951$ method was the smallest. The higher the value of $\mathrm{C} / \mathrm{N}$ was, the 
higher the accumulated temperature of compost was. Adding proper amount of bacteria and wood sorrel can improve the compost temperature.

(4) There was no significant difference in GI among the treatments, and $\mathrm{C} / \mathrm{N}$, fungicide, wood sorrel, the interaction of fungicide and wood sorrel was very significant. This shows that they are all important factors affecting GI, and the optimal combination of $\mathrm{C} / \mathrm{N}$, fungicide and wood sorrel is $\mathrm{C} / \mathrm{N} 31+0.5 \% \mathrm{~m}+\mathrm{W} / 501$, That is, $\mathrm{C} / \mathrm{N} 31+0.5 \%$ bacterial agent + wood sorrel diluted by 501 times.

\section{CONCLUSIONS}

In order to promote the recycling of resources, according to the characteristics of landscape waste, a rapid composting treatment method was studied. The landscape waste in Beijing Xiangshan Park was used as an experimental object to conduct a composting test. The experimental results show that chicken manure and furfural residue can effectively reduce the bulk density of compost, and significantly increase the total porosity and water holding porosity of compost products. Furfural residue can significantly increase the content of total nitrogen in compost. Compared with other treatments, the $\mathrm{C} / \mathrm{N}$ ratio of furfural residue decreased significantly. After composting, the

\section{REFERENCES}

Antonio, P. (2016). Wood products and green chemistry. Ann. For. Sci. 73, 185-203. doi: 10.1007/s13595-014-0448-3

Bolocan, A. S., Bolocan, V., O'Connor, P. M., Coffey, A., Nicolau, A. I., and McAuliffe, O. (2016). Inhibition of listeria monocytogenes biofilms by bacteriocin-producing bacteria isolated from mushroom substrate. J. Appl. Microbiol. 122, 279-293. doi: 10.1111/jam.13337

Chen, Z., Kim, J., and Jiang, X. (2018). Survival of Escherichia coli O157:H7 and Salmonella enterica in animal waste-based composts as influenced by compost type, storage condition and inoculum level. J. Appl. Microbiol. 124, 1311-1323. doi: 10.1111/jam.13719

Gao, L., and Li, C. (2016). Palmprint recognition based on features weighted and kernel principal component analysis. J. Jilin Univ. 54, 1361-1366. doi: 10.13413/j.cnki.jdxblxb.2016.06.31

Hanc, A., Boucek, J., Svehla, P., Dreslova, M., Tlustos, P. (2016). Properties of vermicompost aqueous extracts prepared under different conditions. Environ. Technol. 38, 1428-1434. doi: 10.1080/09593330.2016.1231225

Jin, Y., and Gao, Y. (2016). Optimal piecewise real-time pricing strategy for smart grid. Comp. Simul. 33, 171-175.

Li, Z., Ji, Q., and Zhao, S. (2018). Changes in C and N fractions with composted manure plus chemical fertilizers applied in apple orchard soil: an in-situ field incubation study on the loess plateau, China. Soil Use Manag. 34, 276-285. doi: 10.1111/sum.12417

Lin, Z., Bai, J., and Zhen, Z. (2016). Enhancing pentachlorophenol degradation by vermicomposting associated bioremediation. Ecol. Eng. 87, 288-294. doi: 10.1016/j.ecoleng.2015.12.004

Ling, L., Xiao, P., and Guo, C. (2018). Adsorption behaviors and mechanisms of heavy metal ions on municipal waste composts with different degree of maturity. Environ. Technol. 40, 1-43. doi: 10.1080/09593330.2018.1458908

Qiao, G. (2016). Design and research of landscape platform for mobile devices. Automat. Instrument. 10, 168-169. doi: 10.14016/j.cnki.1001-9227.2016.10.168

Shahid, I., Andrey, K., Guber, H., and Zaman, K. (2016). Estimating nitrogen leaching losses after compost application in furrow irrigated soils of Pakistan using HYDRUS-2D software. Agric. Water Manag. 168, 85-95. doi: 10.1016/j.agwat.2016.01.019

Svetlana, M., Miloš, S., and Biljana, T. (2016). Biological control of green mould on Agaricus bisporus by a native Bacillus subtilis strain from mushroom compost. Eur. J. Plant Pathol. 148, 1-11. doi: 10.1007/s10658-016-1107-3 germination indexes of the three treatments were 73,87 , and $90 \%$, respectively. Except treatment 1, the other two treatments have reached the compost maturity standard. There was no significant difference in GI among the treatments, and $\mathrm{C} / \mathrm{N}$, fungicide, wood sorrel, the interaction of fungicide and wood sorrel was very significant. This shows that they are all important factors affecting GI, and the optimal combination of $\mathrm{C} / \mathrm{N}$, fungicide and wood sorrel is $\mathrm{C} / \mathrm{N} 31+0.5 \% \mathrm{~m}+\mathrm{W} / 501$, That is, $\mathrm{C} / \mathrm{N} 31+0.5 \%$ bacterial agent + wood sorrel diluted by 501 times.

\section{DATA AVAILABILITY STATEMENT}

All datasets generated for this study are included in the article/supplementary files.

\section{AUTHOR CONTRIBUTIONS}

LA did the whole work of the research, used the landscape waste in spring as the main raw material to add proper proportion of dry chicken manure for high temperature composting experiment, analyzed and compared the bulk volume, the changes of $\mathrm{pH}$ and $\mathrm{EC}$ Value, and seed germination index in every treatment, and wrote the manuscript.

Swarnam, T. P., Velmurugan, A., Pandey, S. K., and Dam Roy. S. (2016). Enhancing nutrient recovery and compost maturity of coconut husk by vermicomposting technology. Bioresour. Technol. 207, 76-84. doi: 10.1016/j.biortech.2016.01.046 Touceda-González, M., Álvarez-López, V., Prieto-Fernández, Á., RodríguezGarrido, B., Trasar-Cepeda, C. and Mench, M. (2016). Aided phytostabilisation reduces metal toxicity, improves soil fertility and enhances microbial activity in Cu-rich mine tailings. J. Environ. Manage. 186, 301-313. doi: 10.1016/j.jenvman.2016.09.019

Vergara, S. E., and Tchobanoglous, G. (2012). Municipal solid waste and the environment: a global perspective. Annu. Rev. Environ. Resour. 37, 277-309. doi: 10.1146/annurev-environ-050511-122532

Wei, F., Jie, Y., and Panyue, Z. (2017). Solid-state anaerobic fermentation of spent mushroom compost for volatile fatty acids production by ph regulation. Int. J. Hydrogen Energy 42, 18295-18300. doi: 10.1016/j.ijhydene.2017.04.148

Wu, Q., Li, G., and Chen, W. (2016). An overview of sustainable green 5G networks. IEEE Wirel. Commun. 24, 72-80. doi: 10.1109/MWC.2017.1600343

Yang, B., Zhao, H., Zeng, G., and Zhong, Y. (2016). DC capacitors voltage balancing strategy for cascaded statcom. J. Power Supply 14, 128-136. doi: 10.13234/j.issn.2095-2805.2016.5.128

Yang, H. (2016). Communication power supply monitoring system based on TCP/IP protocol. Chin. J. Power Sources 40, 1298-1299.

Zhang, P., Qin, Z., and Lu, Z. (2016). An analytical model of space backbone network capacity for space information transmission. J. China Acad. Electron. Inf. Technol. 11, 66-72.

Zhu, Y. L., Zheng, G. D., Gao, D., Chen, T. B., Wu, F. K., and Niu, M. J. (2016). Odor composition analysis and odor indicator selection during sewage sludge composting. J. Air Waste Manage. Assoc. 66, 930-940. doi: 10.1080/10962247.2016.1188865

Conflict of Interest: The author declares that the research was conducted in the absence of any commercial or financial relationships that could be construed as a potential conflict of interest.

Copyright (C) 2020 An. This is an open-access article distributed under the terms of the Creative Commons Attribution License (CC BY). The use, distribution or reproduction in other forums is permitted, provided the original author(s) and the copyright owner(s) are credited and that the original publication in this journal is cited, in accordance with accepted academic practice. No use, distribution or reproduction is permitted which does not comply with these terms. 